\title{
PERTUMBUHAN TANAMAN SELADA BERBASIS KEPADATAN IKAN GABUS PADA SISTEM AKUAPONIK
}

\author{
Asriyani $^{1)}$, Aliyaman ${ }^{2}$, Muhammad Noor Azizu ${ }^{3)}$ \\ 1,2,3 Program Studi Agroteknologi, Fakultas Pertanian dan Peternakan \\ Email: asriyani_31@yahoo.com \\ Nomor Tlp : +62 82348588877 \\ Asal Negara : Indonesia
}

\begin{abstract}
ABSTRAK
Tanaman selada mengandung senyawa glukosinolat yang bisa dimanfaatkan untuk mencegah kanker. Salah satu teknik budidaya yang diharapkan dapat meningkatkan kualitas dan produksi dari selada adalah mengintegrasikannya dengan ikan gabus melalui teknik akuaponik Sistem akuaponik dengan memadukan ikan dan tanaman memberi pengaruh yang baik karena feses dan sisa pakan ikan dapat dimanfaatkan tanaman sebagai nutrisi bagi tanaman dan dapat menghemat penggunaan air. Penelitian ini bertujuan untuk mengetahui pertumbuhan dan hasıl prduksı tanaman selada dan ikan gabus dengan sistem akuaponik serta untuk mengetahui pengaruh kepadatan ikan gabus terhadap pertumbuhan dan produksi tanaman selada. Penelitian ini dilaksanakan dalam bentuk Rancangan Acak Kelompok (RAK) dengan perlakuan kepadatan ikan gabus. Perlakuan adalah G1 $=0$ ekor ikan gabus, G2 = 10 ekor ikan gabus, G3 =20 ekor ikan gabus, G4 = 30 ekor ikan gabus dan G5 = 40 ekor ikan gabus Tiap perlakuan diulang 3 kalı, sehingga diperoleh 15 unit percobaan Dari setiap unit percobaan terdapat 10 sampel tanaman, sehingga total keseluruhan sampel tanaman adalah 150 Tanaman. Hasil penelitian memberi pengaruh nyata perlakuan G3S dan G5S. pada pertumbuhan tanaman selada terhadap kepadatan ikan gabus.
\end{abstract}

Kata Kunci: Kepadatan Ikan, Pertumbuhan Tanaman, Akuaponik

ABSTRACT

Lettuce contains high nutritional compounds and glucosinolates which can be used to prevent cancer. One of the cultivation approaches that can improve the quality and quantity of lettuce is integrating lettuce with snakehead fish in aquaponics techniques. The aquaponics have a positive effect because feces and fish meal residues can be utilized as nutrients by plants, which saves water. This study aims to determine the growth and yield of lettuce and snakehead fish with an aquaponic system, as well as what effect of snakehead fish density has on lettuce growth and production. The treatments were $G 1=0$ cork fish, G2 = 10 snakehead fish, G3 = 20 snakehead fish, G4 = 30 snakehead fish and G5 = 40 snakehead fish. Each treatment three times repetition, means there were 15 experimental units. There were ten plant samples from each experimental unit, for a total of 150 plant samples. The result revealed that G3S and G5S had a significant impact on the growth of lettuce plants on the snakehead fish.

\section{Keywords: Fish Density, Plant Growth, Aquaponics}

\section{PENDAHULUAN}

Teknik akuaponik merupakan teknik budidaya tanaman dengan mengintegrasikan antara tanaman dan ikan secara hidroponik dalam satu tempat budidaya. Pada sistem akuaponik ini akan menghasilkan air yang kaya akan nutrisi dari hasil kotoran ikan, yang merupakan sumber pupuk alami yang dapat dimanfaatkan tanaman untuk pertumbuhannya. Menurut Nugroho et al (2012) bahwa prinsip dasar dasar penerapan sistem akuaponik ini dapat dilaksanakan dalam waktu yang bersamaan dalam proses budidayanya sisa pakan dan kotoran dari ikan dapat dimanfaatkan tanaman sebagai tambahan nutrisi dalam pertumbuhannya. Selain itu, budidaya tanaman selada dapat menjadi alternatif dalam menjaga kejernihan dan kualitas air kolam ikan gabus pada sistem akuaponik. Pada sistem ini, akan terjadi proses mikrobial secara alami sehingga ikan dan tanaman tetap sehat. Setyaningsih dan Umar (2015) menyatakan bahwa dalam penerapan sistem dapat memanfaatkan komponen hidroponik sebagai biofilter. Petrea et al (2014). Menambahkan bahwa dengan penggunaan sistem akuaponik ini akan diperoleh hasil panen tanaman yang bermutu tinggi. Menurut Putra et al (2014) produksi hasil tanaman yang dibudidayakan mengalami peningkatan antara 250,8-1.160 g.

Ikan merupakan salah satu sumber protein yang tinggi dan memiliki harga yang terjangkau sedangkan kandungan nutrisi lainnya dapat diperoleh dari sayuran. Salah satu tanaman jenis sayur yang mengandung zat besi dan vitamin yang tinggi dapat diperoleh dari budidaya tanaman selada. Budidaya tanaman selada di Indonesia sudah cukup lama 
dikenal dan telah banyak yang membudidayakannya, namun kegagalan untuk mendapatkan hasil panen tanaman selada masih sering dialami. Sementara itu, kebutuhan pasar akan selada terus meningkat. Untuk meningkatkan kualitas dan produksi hasil selada dengan menerapkan teknik budidaya secara akuaponik.

Penerapan sistem akuaponik akan menjamin ketersediaan oksigen dalam air dan akan menekan kadar amonia yang berlebih sehingga budidaya tanaman dan ikan cukup aman. Sistem akuaponik, menggabungkan antara sistem hidroponik dan akuakultur yang alami. Penerapan sistem akuaponik ini sangat menguntungkan bagi tanaman dan ikan . kandungan amonia yang dihasilkan dari kotoran dan sisa pakan ikan dapat dimanfaatkan sebagai nutrisi bagi tanaman. Rokhman et al (2014) menyatakan bahwa pemanfaatan unsur hara yang berasal dari limbah ikan lebih efektif dengan menerapkan sistem budidaya tanaman dan ikan secara akuaponik Sehingga hasil Produksi yang dihasilkan tinggi. Penelitian ini bertujuan untuk mengetahui pengaruh sistem akuaponik terhadap pertumbuhan dan produksi tanaman selada dan ikan gabus, serta menganalisis perlakuan kepadatan ikan gabus terhadap pertumbuhan dan produksi tanaman selada.

\section{METODE PENELITIAN}

Penelitian dilaksanakan pada bulan Juni sampai November 2021 bertempat di Kabupaten Maros, Kecamatan Lau, Kelurahan Allepolea dan uji laboratorium dilaksanakan di Laboratorium Tanah, Tanaman dan Pupuk Badan Penelitian dan Pengembangan Pertanian Sulawesi Selatan dan Laboratorium Balai Riset Perikanan Budidaya Air Payau dan Penyuluhan Perikanan. Penelitian menggunakan Metode kuantitatif dan uji Laboratorium. Rancangan percobaan yang diterapkan pada penelitian ini adalah Rancangan acak kelompok (RAK) dengan perlakuan kepadatan ikan gabus. Perlakuan adalah G1 = 0 ekor ikan gabus, G2 $=10$ ekor ikan gabus, G3 = 20 ekor ikan gabus, G4 = 30 ekor ikan gabus dan G5 $=40$ ekor ikan gabus. Tiap perlakuan diulang 3 kali, sehingga diperoleh 15 unit percobaan. Data hasil penelitian yang diperoleh apabila ada pengaruh perlakuan pada analisis sidik ragam maka dilakukan uji lanjut menggunakan uji BNT. penelitian ini mencangkup dari persiapan benih, seleksi benih, pembuatan aquaponik, penyemaian, penanaman, pemeliharaan, pengamatan dan panen.

\section{HASIL DAN PEMBAHASAN}

3.1. Tinggi Tanaman

Rata-rata hasil pengamatan dan sidik ragam tinggi tanaman umur 7 hari setelah tanaman HST dan 25 HST pada Tabel 1 menunjukkan bahwa perlakuan tinggi tanaman pada umur 7 HST tidak berpengaruh nyata sedangkan pada umur 25 HST berpengaruh nyata terhadap tinggi tanaman selada.

Tabel 1. Rata-rata tinggi tanaman selada berdasarkan perlakuan kepadatan ikan

\begin{tabular}{ccc}
\hline \multirow{2}{*}{ Perlakuan } & \multicolumn{2}{c}{ Tinggi Tanaman $(\mathrm{cm})$} \\
\cline { 2 - 3 } & $7 \mathrm{HST}$ & $25 \mathrm{HST}$ \\
\hline G1S & 2,93 & $10,09 \mathrm{~b}$ \\
G2S & 3,57 & $10,80 \mathrm{ab}$ \\
G3S & 3,70 & $11,19 \mathrm{a}$ \\
G4S & 3,87 & $11,10 \mathrm{a}$ \\
G5S & 3,67 & $10,97 \mathrm{a}$ \\
\hline
\end{tabular}

Uji BNT 5\%

0,80

Keterangan $=$ Nilai rata-rata yang diikuti huruf $(a b)$ yang sama berarti tidak berbeda nyata terhadap BNT taraf 5\%.

Tabel 1 menunjukkan bahwa tanaman selada di umur 7 HST perlakuan kepadatan ikan 30 ekor (G4S) memberikan tinggi tanaman tertinggi yaitu $3,87 \mathrm{~cm}$ yang disusul perlakuan kepadatan ikan 20 ekor (G3S), kepadatan ikan 40 ekor (G5S), kepadatan ikan 10 ekor (G1S) dan kontrol (G1S). Umur tanaman selada 25 HST menunjukkan bahwa perlakuan kepadatan ikan 20 ekor (G3S) memberikan tinggi tanaman tertinggi yaitu $11,19 \mathrm{~cm}$ tidak berbeda dengan kepadatan ikan 30 ekor (G4S) dan kepadatan ikan 40 ekor (G5S) tidak berbeda nyata dengan kepadatan ikan 10 ekor (G1S) dan berbeda nyata dengan kontrol (G1S).

\subsection{Jumlah Daun}

Rata-rata hasil pengamatan dan sidik ragam jumlah daun umur 7 HST dan 25 HST dapat dilihat pada Tabel 2 . Hasil analisis menunjukkan bahwa perlakuan tidak berpengaruh nyata terhadap jumlah daun tanaman selada.

Tabel 2. Rata-rata tinggi tanaman selada berdasarkan perlakuan kepadatan ikan.

\begin{tabular}{ccc}
\hline & \multicolumn{2}{c}{ Rata-rata Jumlah Daun } \\
Perlakuan & \multicolumn{2}{c}{ (Helai per } \\
\cline { 2 - 3 } & 7 HST & 25 HST \\
\hline G1S & 2,70 & 6,89 \\
G2S & 2,78 & 6,93 \\
G3S & 2,67 & 7,07 \\
G4S & 2,63 & 6,96 \\
G5S & 2,85 & 7,33 \\
\hline Sumber: Data Primer setelah pengamatan, 2021
\end{tabular}

Sumber: Data Primer setelah pengamatan, 2021 
Tabel 2 menunjukkan bahwa tanaman selada umur 7 HST perlakuan kepadatan ikan 40 ekor (G5S) memberikan jumlah daun tertinggi yaitu 2,85 helai per tanaman yang disusul perlakuan kepadatan ikan 10 ekor (G2S), kontrol (G1S), Kepadatan ikan 20 ekor (G3S) dan kepadatan ikan 30 ekor (G4S). Tabel 2 menunjukkan umur tanaman selada 25 HST menunjukkan bahwa perlakuan kepadatan ikan 20 ekor (G3S) memberikan jumlah daun tertinggi, yaitu 7,33 helai per tanaman yang disusul perlakuan kepadatan ikan 20 ekor (G3S), Kepadatan ikan 40 ekor (G5S), Kepadatan ikan 10 ekor (G1S) dan kontrol (G1S).

\subsection{Diameter Batang}

Rata-rata hasil pengamatan dan sidik ragam diameter batang umur 7 HST dan 25 HST dilampirkan pada Tabel 3. Hasil analisis menunjukkan bahwa perlakuan berpengaruh nyata terhadap diameter batang tanaman selada.

Tabel 3. Rata-rata diameter batang tanaman selada berdasarkan perlakuan kepadatan ikan.

\begin{tabular}{clc}
\hline \multirow{2}{*}{ Perlakuan } & \multicolumn{2}{c}{ Diameter Batang Tanaman $(\mathrm{cm})$} \\
\cline { 2 - 3 } & \multicolumn{1}{c}{$7 \mathrm{HST}$} & \multicolumn{1}{c}{$25 \mathrm{HST}$} \\
\hline G1S & $0,80 \mathrm{~b}$ & $7,32 \mathrm{ab}$ \\
G2S & $1,10 \mathrm{a}$ & $7,14 \mathrm{~b}$ \\
G3S & $0,97 \mathrm{ab}$ & $7,33 \mathrm{ab}$ \\
G4S & $1,20 \mathrm{a}$ & $7,23 \mathrm{~b}$ \\
G5S & $1,10 \mathrm{a}$ & $7,64 \mathrm{a}$ \\
\hline Uji BNT 5\% & 0,26 & 0,36 \\
\hline
\end{tabular}

Keterangan = Nilai rata-rata yang diikuti huruf yang sama berarti tidak berbeda nyata terhadap BNT taraf $5 \%$.

Tabel 3 menunjukkan bahwa tanaman selada umur 7 HST dengan perlakuan kepadatan ikan 30 ekor (G4S) memberikan diameter batang terbesar yaitu $1,2 \mathrm{~cm}$ tidak berbeda dengan perlakuan kepadatan ikan 10 ekor (G2S) dan kepadatan ikan 40 (G5S) tidak berbeda nyata dengan kepadatan ikan 20 ekor (G3S) berbeda nyata dengan kontrol (G1S). Umur tanaman selada 25 HST dengan perlakuan kepadatan ikan 40 ekor (G5S) memberikan diameter batang terbesar, yaitu 7,64 tidak berbeda nyata dengan perlakuan kepadatan ikan 20 ekor (G2S) dan kepadatan ikan 0 (G1S) berbeda nyata dengan kepadatan ikan 30 ekor (G4S) dan kepadatan ikan 10 ekor (G2S).

\subsection{Luas Daun}

Rata-rata hasil pengamatan dan sidik ragam luas daun terlihat pada Gambar 1. Hasil analisis menunjukkan bahwa perlakuan tidak berpengaruh nyata terhadap diameter batang tanaman selada.

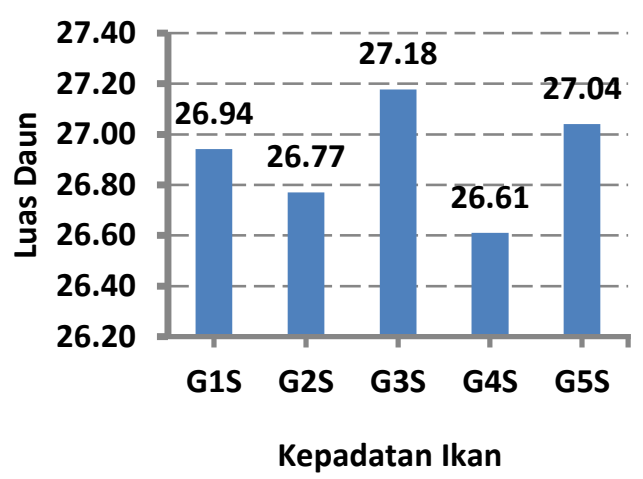

Gambar 1. Rata-rata luas daun tanaman selada perlakuan beberapa kepadatan ikan.

Gambar 1 menunjukkan bahwa perlakuan kepadatan ikan 20 ekor (G3S) memberikan luas daun tertinggi yaitu 27,18 disusul oleh perlakuan kepadatan ikan 40 ekor (G5S), kepadatan Ikan 0 ekor (G1S), kepadatan ikan 10 ekor (G2S) dan kepadatan ikan 30 ekor (G4S).

\subsection{Bobot}

Rata-rata hasil pengamatan dan sidik ragam bobot basah dan bobot kering tanaman selada dapat dilihat pada tabel 4. Hasil analisis menunjukkan bahwa perlakuan berpengaruh nyata terhadap pengamatan bobot basah dan bobot kering tanaman selada.

Tabel 4. Rata-rata bobot basah dan bobot kering tanaman selada berdasarkan perlakuan kepadatan ikan.

\begin{tabular}{ccc}
\hline \multirow{2}{*}{ Perlakuan } & \multicolumn{2}{c}{ Pengamatan (rata-rata) } \\
\cline { 2 - 3 } & $\begin{array}{c}\text { Bobot Basah } \\
\text { (gram) }\end{array}$ & $\begin{array}{c}\text { Bobot Kering } \\
\text { (gram) }\end{array}$ \\
\hline G1S & $36,15 \mathrm{abc}$ & $3,00 \mathrm{a}$ \\
G2S & $37,46 \mathrm{a}$ & $2,84 \mathrm{a}$ \\
G3S & $32,77 \mathrm{c}$ & $2,53 \mathrm{ab}$ \\
G4S & $33,37 \mathrm{bc}$ & $2,35 \mathrm{~b}$ \\
G5S & $37,06 \mathrm{ab}$ & $2,86 \mathrm{a}$ \\
\hline Uji BNT & 3,71 & 0,48 \\
5\% & & \\
\hline
\end{tabular}

Keterangan $=$ Nilai rata-rata yang diikuti huruf yang sama berarti tidak berbeda nyata terhadap BNT taraf $5 \%$.

Tabel 4 menunjukkan pengamatan bobot segar perlakuan kepadatan ikan 10 ekor (G2S) memberikan bobot terberat, yaitu $37,46 \mathrm{~g}$ tidak berbeda nyata dengan perlakuan kepadatan ikan 40 (G5S) dan kepadatan ikan 0 (G1S) dan berbeda nyata dengan kepadatan ikan 30 ekor (G4S) dan kepadatan ikan 20 ekor (G3S). Pengamatan bobot kering perlakuan kepadatan ikan 0 ekor (G1S) memberikan bobot kering terberat. yaitu 3,00 g tidak berbeda dengan perlakuan kepadatan ikan 40 ekor (G5S) dan kepadatan ikan 10 (G2S) tidak berbeda nyata dengan kepadatan ikan 20 ekor (G3S) dan berbeda nyata dengan kepadatan ikan 30 ekor (G4S). 


\subsection{Panjang akar}

Rata-rata hasil pengamatan dan sidik ragam panjang akar tanaman selada ditampilkan pada tabel 5. Hasil analisis menunjukkan bahwa perlakuan berpengaruh nyata terhadap pengamatan panjang akar tanaman selada.

Tabel 5. Rata-rata panjang akar tanaman selada berdasarkan perlakuan kepadatan ikan.

\begin{tabular}{ccc}
\hline Perlakuan & $\begin{array}{c}\text { Rata-Rata Panjang } \\
\text { Akar Tanaman }(\mathrm{cm})\end{array}$ & Uji BNT 5\% \\
\hline G1S & $15,53 \mathrm{ab}$ & \\
G2S & $16,16 \mathrm{a}$ & 0,85 \\
G3S & $14,99 \mathrm{~b}$ & \\
G4S & $15,50 \mathrm{ab}$ & \\
G5S & $16,00 \mathrm{a}$ & \\
\hline
\end{tabular}

Keterangan $=$ Nilai rata-rata yang diikuti huruf yang sama berarti tidak berbeda nyata terhadap BNT taraf $5 \%$.

Tabel 5 menunjukkan perlakuan kepadatan ikan 10 ekor (G2S) memberikan panjang akar tertinggi yaitu $16,16 \mathrm{~cm}$ tidak berbeda dengan perlakuan kepadatan ikan 40 (G5S) tidak berbeda nyata dengan perlakuan kepadatan ikan 0 (G1S) kepadatan ikan 30 ekor (G4S) dan berbeda nyata dengan perlakuan kepadatan ikan 20 ekor (G3S).

\subsection{Panjang Ikan}

Rata-rata hasil pengamatan Panjang ikan umur 8 minggu setelah sebar terlihat pada Gambar 2.

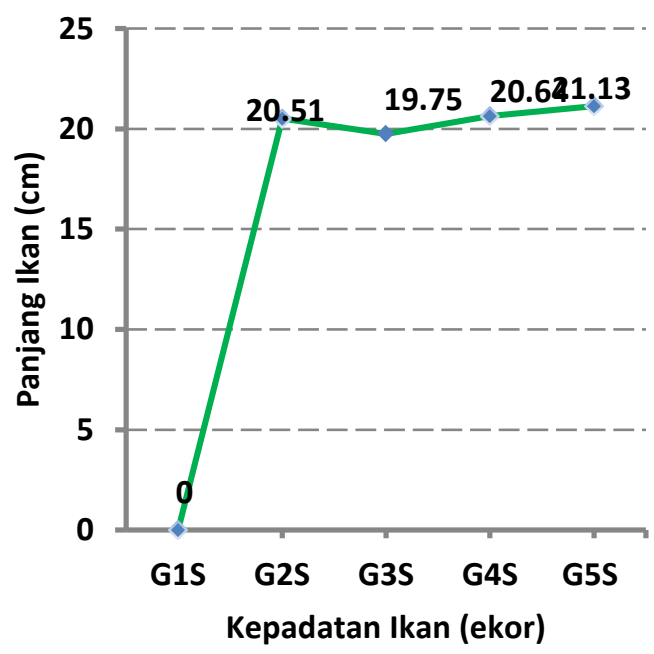

Gambar 2. Rata-rata pengamatan panjang ikan perlakuan kepadatan ikan

Gambar 2 menunjukkan bahwa perlakuan kepadatan ikan 40 ekor (G5S) memberikan panjang ikan tertinggi yaitu $21,13 \mathrm{~cm}$ yang disusul perlakuan kepadatan ikan 30 ekor (G4S), kepadatan ikan 10 ekor (G2S), kepadatan ikan 20 ekor (G3S) dan kepadatan ikan 0 ekor (G1S).

\subsection{Bobot Ikan}

Rata-rata hasil pengamatan bobot ikan umur 4 dan 8 minggu setelah sebar (mst) dapat dilihat padat Gambar 3.

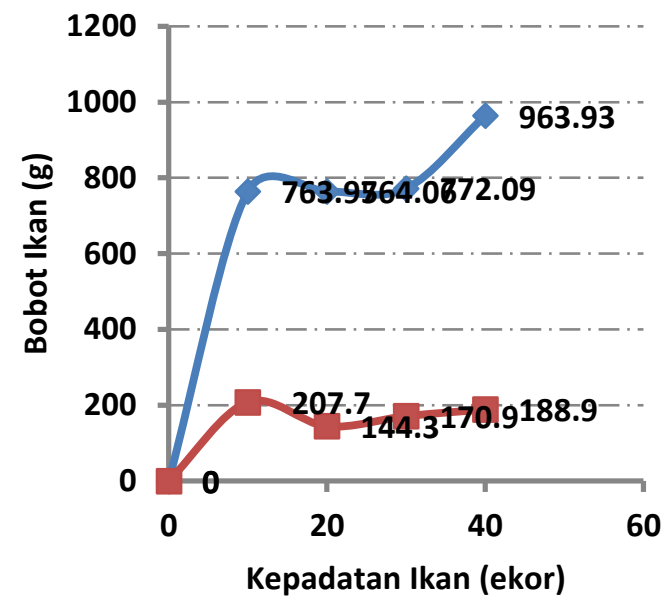

Gambar 3. Rata-rata pengamatan bobot ikan perlakuan kepadatan ikan.

Gambar 3 menunjukkan bahwa ikan umur 4 mst perlakuan kepadatan ikan 10 ekor (G1S) memberikan bobot ikan tertinggi yaitu 207,7 g yang disusul perlakuan kepadatan ikan 40 ekor (G5S), kepadatan ikan 30 ekor (G4S), dan kepadatan ikan 20 ekor (G3S).

Gambar 3 menunjukkan umur ikan 8 mst menunjukkan bahwa perlakuan kepadatan ikan 40 ekor (G5S) memberikan bobot ikan tertinggi yaitu 963,93 g yang disusul perlakuan kepadatan ikan 10 ekor (G2S), Kepadatan ikan 30 ekor (G4S), kepadatan ikan 20 ekor (G3S).

\subsection{Kelangsungan Hidup Ikan}

Rata-rata hasil pengamatan kelangsungan hidup ikan didapatkan hasil sebagai berikut:

Tabel 6. Rata-rata kelangsungan hidup (\%) tanaman selada perlakuan kepadatan ikan.

Kepadatan Ikan Kelangsungan Hidup (\%)

\begin{tabular}{cc}
\hline 10 & 100 \\
20 & 85 \\
30 & 93 \\
40 & 90 \\
\hline Sumber: Data Primer setelah diolah, 2021
\end{tabular}

Tabel 6 menunjukkan bahwa kepadatan ikan 10 ekor (G2S) memberikan hasil $100 \%$ yang artinya bahwa tidak ada kematian pada perlakuan tersebut kemudian disusul perlakuan kepadatan ikan 30 ekor (G4S), kepadatan ikan 40 ekor (G5S) dan kepadatan ikan 20 ekor (G3S). 


\subsection{Biomassa}

Rata-rata hasil pengamatan biomassa ikan didapatkan hasil sebagai berikut (gambar 4) :

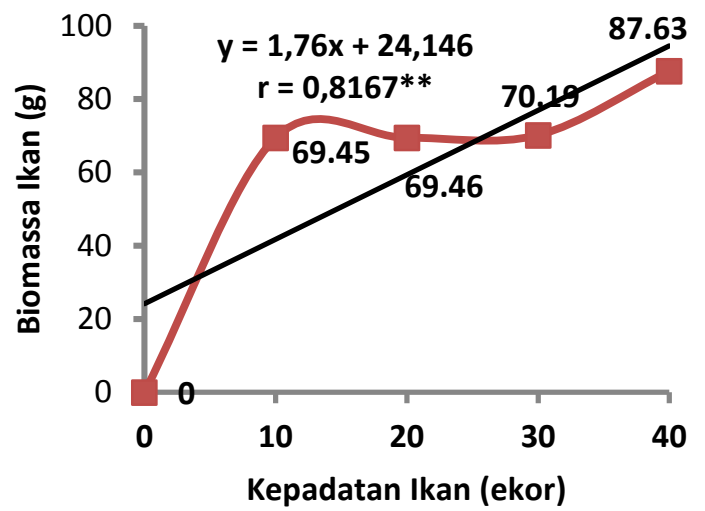

Gambar 4. Rata-rata pengamatan biomassa ikan perlakuan kepadatan ikan.

Gambar 4 menunjukkan bahwa perlakuan kepadatan ikan 40 ekor (G5S) memberikan biomassa tertinggi yaitu $87,63 \mathrm{~g}$ kemudian disusul perlakuan kepadatan ikan 30 ekor (G4S), Kepadatan ikan 20 ekor (G3S), kepadatan ikan 10 ekor (G2S), dan Kepadatan ikan 0 ekor (G1S).

Gambar 3 menunjukkan bahwa pengamatan bobot ikan umur 8 minggu memiliki keterkaitan antara kepadatan ikan dengan bobot ikan, hal ini sesuai dengan persamaan $\mathbf{y}=\mathbf{1 , 7 6} x+\mathbf{2 4 , 1 4 6 ,}, \mathbf{r}=$

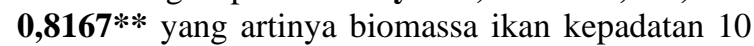
ekor memiliki 41,76 g, perlakuan kepadatan ikan 20 ekor memiliki biomassa yaitu 59,34 g, perlakuan kepadatan ikan 30 ekor memiliki biomassa yaitu $79,94 \mathrm{~g}$ dan perlakuan kepadatan ikan 40 ekor memiliki biomassa yaitu 94,54 $\mathrm{g}$.

\subsection{Analisis Kandungan $\mathbf{N}, \mathbf{P}$ dan $K$}

Hasil analisis kandungan N,P dan K pada tanaman selada menggunakan metode pengujian Kjeldahl Spektrofotometri AAS ditampilkan pada tabel 7 yang menunjukkan bahwa serapan hara $\mathrm{N}$ tertinggi yaitu $3.86 \%$, serapan hara $\mathrm{P}$ tertinggi, yaitu $0.32 \%$, dan serapan hara K tertinggi, yaitu $6.59 \%$ terdapat pada tanaman selada.

Tabel 7.

Analisis jaringan serapan hara pada tanaman

\begin{tabular}{cccc}
\hline & \multicolumn{3}{c}{ Parameter Terukur \% } \\
Perlakuan & $\mathbf{N}$ & $\mathbf{P}$ & $\mathbf{K}$ \\
\hline G1S & 3,29 & 0,12 & 4.76 \\
G2S & 3,86 & 0,25 & 4,83 \\
G3S & 3,48 & 0,24 & 5,74 \\
G4S & 3,56 & 0,32 & 5,07 \\
G5S & 3,58 & 0,23 & 6,59 \\
\hline Sumber: Data Primer 2021 & &
\end{tabular}

Terdapat interaksi Tanaman selada dan kepadatan ikan Gabus pada sistem Akuaponik, hal ini dapat dilihat dari hasil Uji Statistik. Dimana pada hasil pengamatan melalui pertumbuhan tinggi tanaman, diameter batang, bobot segar dan bobot kering serta panjang akar pada tanaman selada menunjukan hasil yang berpengaruh nyata terhadap pertumbuhan tanaman selada, hal ini disebabkan karena tanaman dapat menyerap unsur hara Nitrogen , Fosfor dan Kalium pada tanaman secara optimal. Hal ini sangat berkaitan dengan pernyataan Damanik, (2011) bahwa akar tanaman akan lebih mudah menyerap unsur hara nitrogen apabila unsur ini bereaksi dengan air sehingga dapat menunjang pertumbuhan vegetatif pada tanaman . Bahan organik yang terdapat di dalam air dapat dimanfaatkan oleh tanaman sebagai nutrisi sehingga jumlah toksik yang terdapat dalam air dapat diminimalisir kandungannya .

Hasil penelitian menunjukkan bahwa serapan hara tanaman selada pada hasil analisis laboratorium serapan hara $\mathrm{N}$, p, dan $\mathrm{K}$ pada tanaman selada memberikan hasil yang normal, pada kondisi pemberian pupuk yang mengandung unsur $\mathrm{N}$, p dan $\mathrm{K}$ pada tanaman dan kebutuhan tanaman akan unsur hara juga diperoleh dengan memanfaatkan kotoran ikan sebagai pupuk tambahan sehingga dapat menunjang pertumbuhan tanaman. Sistem akuaponik ini akan menghasilkan produk tanaman yang berkualitas dan budidaya tanaman dan ikan yang ramah lingkungan.

Pada penelitian yang dilakukan oleh Putra,dkk., (2013) menyatakan bahwa produksi yang akan meningkatkan hasil pada tanaman, dengan adanya penyerapan unsur hara yang optimal pada akar tanaman. Hal ini juga ditunjang oleh nutrisi yang diperoleh tanaman dari kotoran sisa pakan dan feses ikan sehingga akan menghasilkan tanaman yang subur.

Pemeliharaan ikan gabus memberi peranan penting dalam proses budidaya akuaponik yang ramah lingkungan dan hemat energi karena air yang mengalir dari kolam pemeliharaan ikan gabus dimanfaatkan sebagai sumber hara tambahan untuk pertumbuhan tanamaan selada kerana air yang terdapat dalam kolam sudah mengalami proses biofiltrasi Sehingga limbah dari budidaya ikan berfungsi sebagai pupuk organik bagi tanaman (Wahap, et al., 2010).

Hasil pengamatan ikan gabus menunjukkan bahwa kelangsungan hidup ikan berkisar $85 \%$ sampai dengan $100 \%$, serta pertambahan panjang dan bobot ikan mengalami pertumbuhan dan perkembangan yang optimal. Hal ini sangat dipengaruhi beberapa faktor, yaitu konsentrasi amonia, pH, Suhu, Nitrat dan Kandungan Oksigen terlarut didalam air yang mendukung kelangsungan hidup ikan gabus yang dibudidayakan dengan tanaman selada Kadar keasaman pH selama penelitian berkisar 5-7 Kondisi ini cenderung netral 
karena proses Nitrifikasi yang berlangsung didalamnya melibatkan Bakteri Sehingga kondisi air dapat netral. Menurut Putra dkk., (2013) menyatakan bahwa kondisi $\mathrm{pH}$ yang rendah dan $\mathrm{pH}$ yang tinggi dapat mempengaruhi kelangsungan hidup ikan karena pada umumnya ikan dapat hidup dengan baik pada $\mathrm{pH}$ berkisar 5-9. Sedangkan menurut Syamsuddin (2014) menyatakan bahwa untuk penggunaan air tawar pada kolam ikan pHnya berkisar antara 6,5 - 9,0. Rata-rata pengamatan pada setiap perlakuan menunjukkan hasil pengukuran suhu berkisar antara $24^{\circ} \mathrm{C}-26^{\circ} \mathrm{C}$. Nilai suhu di kolam Gabus dari awal sampai akhir pemeliharaan cenderung stabil. Hal ini sesuai dengan pendapat Putra dkk., (2013) menyatakan bahwa kondisi suhu tersebut masih tergolong baik untuk organisme di daerah tropis adalah $25^{\circ} \mathrm{C}-32^{\circ} \mathrm{C}$. Suhu air sangat penting dalam sistem akuaponik, jika terlalu panas oksigen akan hilang karena air tidak mampu menahan banyak oksigen.

\section{KESIMPULAN DAN SARAN}

\section{Kesimpulan}

1. Penerapan Sistem Akuaponik memberi pengaruh yang baik terhadap kualitas air kolam sehingga pertumbuhan tanaman selada dan kelangsungan hidup ikan gabus optimal hal ini bisa dilihat bahwa perlakuan terbaik terdapat pada perlakuan kepadatan ikan G3S(20 ekor ikan Gabus pada tanaman selada) dan G5S (40 ekor ikan Gabus pada tanaman Selada).

2. Terdapat Interaksi yang memberi pengaruh nyata antara tanaman Selada dan kepadatan ikan gabus terhadap pertumbuhan tinggi tanaman, diameter batang, bobot segar dan bobot kering, panjang akar, bobot ikan dan kelangsungan hidup ikan.

\section{Saran}

Perlu dilakukan penelitian lebih lanjut mengenai budidaya tanaman selada secara organik pada sistem akuaponik.

\section{UCAPAN TERIMA KASIH}

Penulis mengucapkan terima kasih kepada kementerian riset dan teknologi atau badan riset dan inovasi nasional yang telah membiayai penelitian bagi para dosen pemula serta ucapan terima kasih kepada universitas muslim buton yang telah mendukung kami dalam penelitian ini.

\section{DAFTAR PUSTAKA}

Damanik, C. 2011. Faktor-faktor Yang Menjadi Kendala dalam Penerapan SAP pada Pemerintah Kota Binjai. Skripsi. Jurusan Akuntansi. Universitas Sumatera Utara.

Nugroho, R.A., Pambudi, L.T., Hilmawati, D., dan Haditomo, A.H.C. 2012. Aplikasi teknologi akuaponik pada budidaya ikan air tawar untuk optimalisasi kapasitas produksi. Saintek Perikanan, 8 (1):

Setyaningsih, L., dan Umar, C. 2015. Pengaruh lama retensi air terhadap pertumbuhan ikan nila (Oreochromis niloticus) pada budidaya sistem akuaponik dengan tanaman kangkung. Berita Biologi, 14 (3): 267-275

Petrea, S.M., Cristea, C., Dediu, L., Contoman, M. Stroe, M.D., Antache, A., Coada, M.T., and Placinta, S. 2014. Vegetable production in an integrated aquaponic system with stellate sturgeon and spinach-matador variety: Animal Science and Biotechnologies, 24 (1): 235-245.

Putra, I., Mulyadi., Pamukas, N.A., dan Rusliadi. 2013. Peningkatan kapasitas produksi akuakultur pada pemeliharaan ikan selais (Ompok sp) sistem aquaponik. Perikanan dan Kelautan, 18 (1): 1-10.

Rokhman, N.A., Ammatillah, C.S., dan Sastro, Y. 2014. Vertiminaponik, mini akuaponik untuk lahan sempit di perkotaan. Buletin Pertanian Perkotaan, 4 (2) : 14-22

Syamsuddin, R. 2014. Pengelolaan Kualitas Air, Teori dan Aplikasi di Sektor Penarikan. Pijar Press. Makassar.

Wahap, N., Estim, A., Kian, A.Y.S., Senoo, S and Mustafa, S. 2010. Producing Organic Fish and Mint in an Aquaponic System, 319. Borneo Marine Research Institute, Sabah, Malaysia. 